\title{
Downscaling standardized precipitation index via model output statistics
}

\author{
HASAN TATLI \\ Çanakkale Onsekiz Mart University, Faculty of Sciences and Arts, Department of Geography, Physical Geography \\ Division, Climatology/Meteorology Group, Terzioğlu Campus, 17020 Çanakkale, Turkey \\ E-mail: tatli@comu.edu.tr, tatli.hasan@gmail.com
}

Received: December 10, 2013; accepted: February 4, 2015

\begin{abstract}
RESUMEN
El presente estudio analiza los posibles impactos futuros del cambio climático sobre los eventos meteorológicos de sequía en Turquía, utilizando para ello una nueva técnica estadística de reducción de escala (downscaling) basada en regresión logística politómica. Esta técnica, conocida como "estadísticas de salida del modelo" (model output statistics, MOS), está diseñada para la reducción de escala de las categorías de sequía del índice estandarizado de precipitación (SPI, por sus siglas en inglés). El principal objetivo de un procedimiento de reducción de escala es determinar la influencia de la variabilidad climática de gran escala y los cambios proyectados en las variables a nivel regional y local. Los predictores de gran escala utilizados en este estudio se obtuvieron a partir de simulaciones del modelo canadiense de circulación general acoplado de segunda generación (CGCM2, por sus siglas en inglés), las cuales abarcan de 1940 a 2100 e incluyen tres escenarios socioeconómicos: control, con los límites de la concentración atmosférica de gases de efecto invernadero en el siglo XX, y los escenarios A2 y B2 del Informe especial sobre escenarios de emisiones del Panel Intergubernamental de Cambio Climático. Se utilizaron observaciones de 96 estaciones meteorológicas para calcular los valores anuales del SPI para el periodo 1940-2010, dejando los últimos 10 años para validación contra los resultados simulados por el CGCM2. Los resultados del MOS derivados de la simulación del clima denominada control coincidieron con los patrones observados en el clima actual. Los resultados del MOS derivados de escenarios climáticos futuros llevan a concluir que hay una probabilidad disminuida de que se presenten condiciones muy húmedas o extremadamente húmedas. Adicionalmente, las probabilidades de que las condiciones sean cercanas a lo normal disminuirán en la costa del Mar Negro, y aumentarán en la transición del Mármara y en Anatolia oriental.
\end{abstract}

\begin{abstract}
This study investigates the possible impacts of future climate change on meteorological drought events in Turkey by using a new statistical downscaling technique based on polytomous logistic regression, denoted as the model output statistics (MOS) technique. It is designed to downscale the drought classes of the 12-month Standardized Precipitation Index (SPI). The main goal of a downscaling procedure is to determine the influences of large-scale climatic variability and the projected changes on the local scale-regional variables. The large-scale predictors used in this study were obtained from the output of the Second Generation Canadian Coupled General Circulation Model (CGCM2) simulations, run from 1940 to 2100 for three socioeconomic scenarios, namely control, with the constraint of the 20th century atmospheric concentration of greenhouse gases, and the SRES A2 and B2 scenarios. Observations from 96 meteorological stations were used to estimate 12-month SPI values for the period 1940-2010, leaving the last 10 years for validation against the results simulated by the CGCM2. The MOS results derived from the control climate simulation agree with the observed patterns for present climate. The MOS results derived from future climate scenarios lead to conclude that there is a decreased probability of very wet and extremely wet conditions. In addition, the probabilities of near-normal conditions will decrease in the Black Sea coast and will increase towards the Marmara Transition and continental eastern Anatolia regions.
\end{abstract}

Keywords: Climate of Turkey, statistical downscaling, logistic regression, standard precipitation index (SPI). 


\section{Introduction}

Droughts in any form in the meteorological, hydrological and agricultural fields are the anticipated results of climate change, particularly in subtropical regions including the Mediterranean countries. Droughts will become more prevalent and thus, more complex water management and drought monitoring tools will be required (IPCC, 2001, 2007). The impacts of climate change on future weather and climate are generally evalauted by running general circulation models (GCMs) based on various scenarios.

The Mediterranean region, including Turkey, is one of the areas in which GCMs simulate decreases in precipitation. For instance, Ozturk et al. (2012) have investigated the annual time-scale performance of the regional climate model RegCM4.0 in simulating annual change of dry-spells and extreme-precipitation in the central Asian region by running the model for two 30 -yr. periods (1971-2000 and 2071-2100). They used the ERA40 reanalysis as boundary conditions of the regional climate model for the present period (control) and global datasets of EH5OM for the future with the IPCC SRES A1B scenario. They concluded that the southern part of Central Asia will be most vulnerable for droughts in the future, and there will be an increase in extreme drought conditions over almost the whole region.

However, simulations of the GCMs at coarse resolution may contain inherent inconsistent variability in climate variables. In view of that, a downscaling process is necessary to reduce uncertainty. For example, in a water management plan, the possible impacts of climate change on precipitation are remarkably important for local-scale studies, but the resolution of the GCMs is not suitable; hence, the scale-gap should be bridged with the local-scale variables (i.e., precipitation). This can be achieved either by empirical-statistical downscaling (which also includes probabilistic weather generators, etc.), or by physical-dynamical downscaling (e.g., Karl et al., 1990; Wilby et al., 1999; Easterling, 1999; Timothy and Hulme, 1999; Tatli et al., 2004, 2005; Coulibaly et al., 2005; Fowler et al., 2007; Tolika et al., 2007; Anandhi et al., 2008; Radu et al., 2008; Hertig and Jacobeit, 2008; Tatli, 2013).

Many useful techniques have been suggested in traditional statistical-downscaling procedures, such as linear and nonlinear regression, artificial neural networks (ANNs), canonical correlation analysis (CCA) and weather generator, which are are examples of methods for deriving relationships between large-scale predictors and local-scale predictands (Semenov and Barrow, 1997; Conway and Jones, 1998; Wilby et al., 1998; Kocak et al., 2004; Tatli et al., 2004, 2005; Dibike and Coulibaly, 2006; Loukas et al., 2008; Schmith, 2008; Mishra and Singh, 2009; Mishra et al., 2009; Vasiliades et al., 2009; Tatli, 2013).

Additionally, other studies have proposed are dealing with new methods, concepts, comparative studies and modeling, and have been applied in many fields (e.g., Wilby and Wigley, 1997; Huth et al., 2000, Hay and Clark, 2003; Fowler et al., 2007; Mascaro et al., 2008).

Monitoring drought via the standard precipitation index (SPI) was first introduced by McKee et al. (1993, 1995), and found immediate applications in many fields (e.g., Guttman, 1998, 1999; Hayes et al., 1999; Wilhelmi and Wilhite, 2002; Steinemann, 2003; Wu et al., 2005; Türkeş and Tatli, 2009; Vasiliades et al., 2009). The SPI approach has several advantages including its simplicity and temporal flexibility, which allow its application to water resources on all timescales. For instance, Hayes et al. (1999), based on a case study of drought in Texas, concluded that the SPI method is an important tool that could be operationally used in a local, state, regional, or national drought monitoring system in the United States.

In this study, a statistical-downscaling model based on the logistic regression technique is suggested for downscaling 12-month SPI values using large-scale precipitation series on the four nearest grid points around the selected station. The largescale simulated precipitation values are used as predictors, and logistic regression is suggested as a downscaling technique for projecting future SPI values. The paper proceeds as follows: Section 2 describes the employed methods. Results are given in Section 3. Finally, Section 4 comprises the conclusions.

\section{Data and methodology}

\subsection{Data and study area}

The dataset of local-scale variables used in this study is the monthly precipitation records of the Turkish 
State Meteorological Service. The selected meteorological stations provide a suitable spatial distribution of the rainfall regions (Fig. 1, Table I) of Turkey.

The large-scale predictors needed for the study were extracted from the precipitation series simulated by the Second Generation Canadian Coupled General Circulation Model (CGCM2) of the Canadian Centre for Climate Modeling and Analysis (CCCma). For more details about the CGCM2 one may refer to the website of the CCCma (http://www.cccma. ec.gc.ca/models/models.shtm), Flato et al. (2000), or the IPCC data distribution center (http://www. mad.zmaw.de/IPCCDDC/html/ddcgemdata.html). The atmospheric component of CGCM2 is a spectral model with triangular truncation at wave number 32 and a surface grid resolution of roughly $3.75 \times 3.75^{\circ}$ with 10 vertical levels.

\subsection{Methodology}

A logistic regression technique is used in this study to statistically downscale results from simulations of a global climate model with coarse resolution. Some definitions are needed for clarifying the question of how a logistic regression can be used as a downscaling technique. In simple logistic regression, the dependent variable (i.e., predictand) is usually dichotomous or binary, that is, the predictand can assume the value of 1(one) with a probability of $P$ for success and the value of 0 (zero) with a probability of 1- $P$ for failure. However, the logistic regression can also be extended to cases where the dependent variable can take more than two values, known as multinomial or polytomous (Aldrich and Nelson, 1984; Menard, 1995; Tabachnick and Fidell, 1996; Kleinbaum and Klein, 2002; Preisler and Westerling, 2007; Prasad et al., 2010). The logistic regression is more powerful than other linear regression models, and it makes no assumption on the probability distribution of the predictors. The probability distribution in question needs not to be normally distributed, linearly related or have an equal variance within each group; these restrictions are needed in the traditional linear regression applications. The relationships are derived from the so-called logit-transformation by the success probability of:

$$
P(x)=\frac{\exp \left(b_{0}+b_{1} x_{1}+b_{2} x_{2}+\cdots+b_{n} x_{n}\right)}{1+\exp \left(b_{0}+b_{1} x_{1}+b_{2} x_{2}+\cdots+b_{n} x_{n}\right)}
$$

where $x_{i}(i=1,2, \ldots, n)$ is the predictor and $b_{i}(i=$ $0,1,2, \ldots, n)$ is the coefficient of logistic regression. Since logistic regression estimates the probability of success over the probability of failure, the results of the analysis could be put as odd ratios in the following expression:

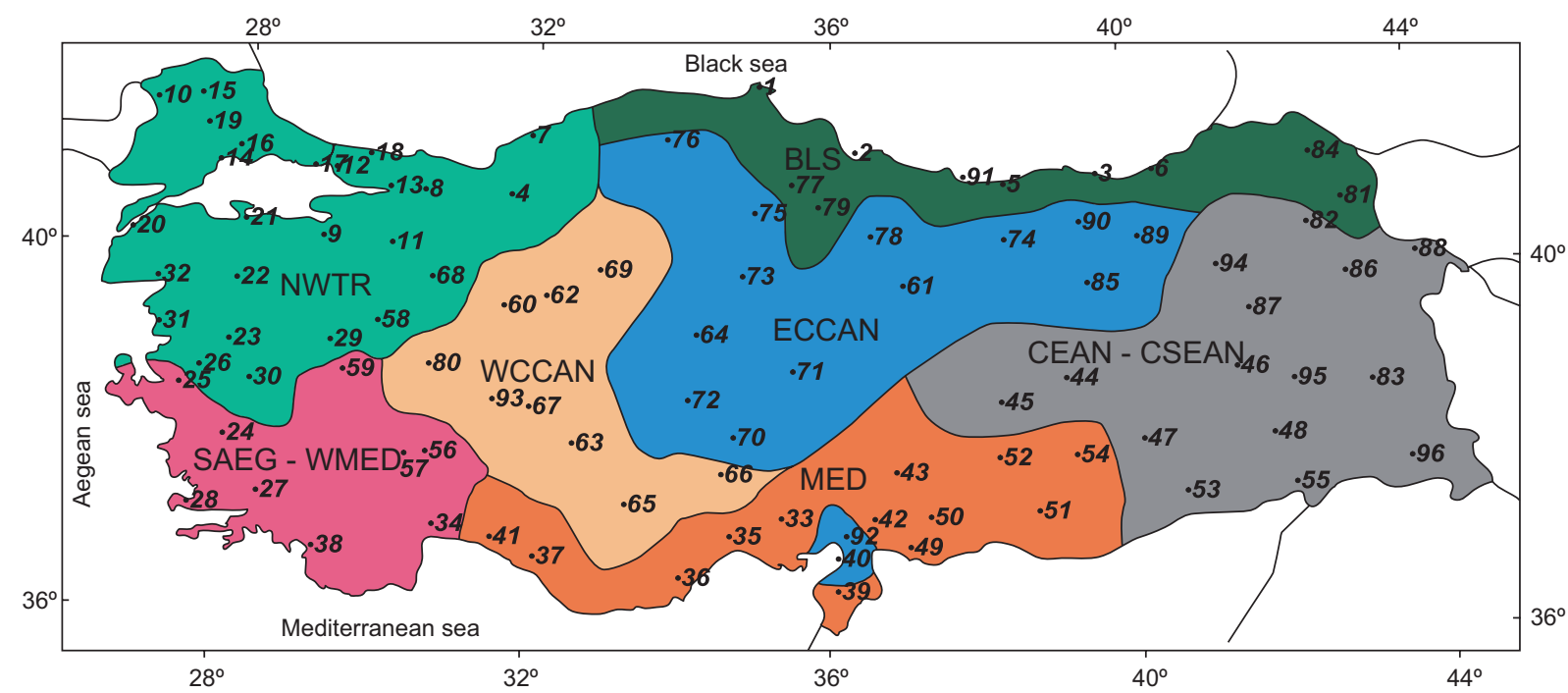

Fig. 1. The rainfall regions of Turkey according to Türkes and Tatli (2011). The stations used in this study are numbered on the map, and their identifier can be found in Table I. BLS: Black Sea; NWTR: northwest Turkey; SAEGWMED: southern Aegean and western Mediterranean; MED: Mediterranean; W-CCAN: west continental Central Anatolia; E-CCAN: east continental Central Anatolia; CEAN-CSEAN: continental eastern and southeastern Anatolia. 
Table I. Meteorological stations of Turkey used in this study, arranged according to the sequence numbers of the map in Figure 1.

\begin{tabular}{|c|c|c|c|c|c|c|c|c|}
\hline Station name & $\begin{array}{l}\text { Longitude } \\
\text { (east) }\end{array}$ & $\begin{array}{l}\text { Latitude } \\
\text { (north) }\end{array}$ & Station name & $\begin{array}{l}\text { Longitude } \\
\text { (east) }\end{array}$ & $\begin{array}{l}\text { Latitude } \\
\text { (north) }\end{array}$ & Station name & $\begin{array}{l}\text { Longitude } \\
\text { (east) }\end{array}$ & $\begin{array}{l}\text { Latitude } \\
\text { (north) }\end{array}$ \\
\hline Sinop & 35.2 & 42.0 & Adana & 35.4 & 37.0 & Karaman & 33.2 & 37.2 \\
\hline Samsun & 36.3 & 41.3 & Antalya & 31.6 & 37.1 & Ulukisla & 34.5 & 37.6 \\
\hline Trabzon & 39.7 & 41.0 & Mersin & 34.6 & 36.8 & Ilgin & 31.9 & 38.3 \\
\hline Bolu & 31.6 & 40.7 & Silifke & 33.9 & 36.4 & Eskisehir & 30.5 & 39.8 \\
\hline Giresun & 38.4 & 40.9 & Alanya & 34.6 & 36.8 & Ankara & 32.9 & 40.0 \\
\hline Rize & 40.5 & 41.0 & Fethiye & 29.1 & 36.6 & Nigde & 34.7 & 38.0 \\
\hline Zonguldak & 31.8 & 41.5 & Antakya & 36.2 & 36.2 & Kayseri & 35.1 & 38.9 \\
\hline Sakarya & 30.4 & 40.8 & Iskenderun & 36.2 & 36.6 & Aksaray & 34.1 & 38.4 \\
\hline Bursa & 29.1 & 40.2 & Manavgat & 31.4 & 36.8 & Yozgat & 34.8 & 39.8 \\
\hline Edirne & 26.6 & 41.7 & Islahiye & 36.6 & 37.0 & Sebinkarahisar & 38.4 & 40.3 \\
\hline Bilecik & 30.0 & 40.2 & Kahramanmaras & 36.9 & 37.6 & Corum & 35.0 & 40.6 \\
\hline Goztepe & 29.1 & 41.0 & Elazig & 39.3 & 38.7 & Kastamonu & 33.8 & 41.4 \\
\hline Kocaeli & 29.9 & 40.8 & Malatya & 38.3 & 38.4 & Merzifon & 35.5 & 40.9 \\
\hline Tekirdag & 27.3 & 40.9 & Mus & 41.5 & 38.7 & Tokat & 36.6 & 40.3 \\
\hline Kirklareli & 27.2 & 41.7 & Diyarbakir & 40.2 & 37.9 & Amasya & 35.9 & 40.7 \\
\hline Corlu & 27.8 & 41.2 & Siirt & 42.0 & 37.9 & Afyon & 30.5 & 38.8 \\
\hline Florya & 28.8 & 41.0 & Kilis & 37.1 & 36.7 & Kars & 43.1 & 40.6 \\
\hline Sile & 29.6 & 41.2 & Gaziantep & 37.4 & 37.1 & Sarikamis & 42.6 & 40.3 \\
\hline Luleburgaz & 27.4 & 41.4 & Sanliurfa & 38.8 & 37.1 & Van & 43.3 & 38.5 \\
\hline Canakkale & 26.7 & 40.1 & Adiyaman & 38.3 & 37.8 & Ardahan & 42.7 & 40.1 \\
\hline Bandirma & 28.0 & 40.4 & Mardin & 40.7 & 37.3 & Erzincan & 39.5 & 39.8 \\
\hline Balikesir & 27.9 & 39.7 & Siverek & 39.3 & 37.8 & Agri & 43.1 & 39.7 \\
\hline Akhisar & 27.9 & 38.9 & Cizre & 42.2 & 37.3 & Hinis & 41.7 & 39.4 \\
\hline Aydin & 27.8 & 37.9 & Isparta & 30.6 & 37.8 & Igdir & 44.1 & 39.9 \\
\hline Izmir & 27.2 & 38.4 & Burdur & 30.3 & 37.7 & Bayburt & 40.2 & 40.3 \\
\hline Manisa & 27.5 & 38.6 & Kutahya & 30.0 & 39.4 & Gumushane & 39.5 & 40.5 \\
\hline Mugla & 28.4 & 37.2 & Usak & 29.4 & 38.7 & Ordu & 37.9 & 41.0 \\
\hline Bodrum & 27.4 & 37.0 & Sivrihisar & 31.5 & 39.5 & Dortyol & 36.2 & 36.9 \\
\hline Simav & 29.0 & 39.1 & Sivas & 37.0 & 39.9 & Aksehir & 31.4 & 38.4 \\
\hline Salihli & 28.1 & 38.5 & Polatli & 32.2 & 39.6 & Erzurum & 41.2 & 40.0 \\
\hline Dikili & 26.9 & 39.1 & Konya & 32.6 & 38.0 & Tatvan & 42.3 & 38.5 \\
\hline Edremit & 27.0 & 39.6 & Kirsehir & 34.2 & 39.1 & Hakkari & 43.8 & 37.6 \\
\hline
\end{tabular}

$$
\begin{aligned}
\log i t[P(x)] & =\ln [\text { odds }]=\ln \left[\frac{P(x)}{1-P(x)}\right] \\
& =b_{0}+b_{1} x_{1}+b_{2} x_{2}+\cdots+b_{n} x_{n}
\end{aligned}
$$

The logistic regression is structurally similar to the well-known multivariate linear regression, where the logits act as predictors and the predictands are natural logarithms of the success probabilities (i.e., the odds).

The coefficients are generally obtained by using the weighted Newton-Raphson algorithm. This method is attractive, because the response variables can be naturally arranged as a sequence of binary choices. For this reason, it is a very suitable approach to categorize drought events. The application steps of this method are briefly summarized below according to Tabachnick and Fidell (1996), and Kleinbaum and Klein (2002):

1. Choose initial estimates of the regression coefficients, $b^{T}=0$.

2. At each iteration step $k$, update the coefficients,

$b_{k}=b_{k-1}+\left(X^{T} V_{k-1} X\right)^{-1} X^{T}\left(y-p_{k-1}\right)$

where $X$ and $y$ are treated as large-scale predictors and predictands (containing zeros and ones), and $V_{k-1}$ is the weight matrix where the diagonal entries $p_{i, k-1}\left(1-p_{k-1}\right)$ represent the occurrence probability. Step 2 is repeated until $b_{k}$ is close enough to $b_{k-1}$. The estimated asymptotic covariance matrix of the coef- 
ficients is given by $\left(X^{T} V X\right)^{-1}$. The Newton-Raphson algorithm can be extended to a higher dimensional version (polytomous), and its parameters are illustrated with the vector of $p_{k-1}$ in Eq. 3. The method is a multivariate regression model of the so-called conditional multinomial logistic regression.

The predictors illustrated with the matrix $X$ are selected from the output of the simulation with the CGCM2, which is used to produce ensemble climate change projections using the IPCC's older IS92a forcing scenarios, as well as the newer SRESA2 and SRESB2 scenarios (IPCC, 2000). Note that the results of the CGCM2 are also used in the third assessment report of the IPCC (IPCC, 2001), and in the Arctic climate impact assessment.

The suggested procedure is schematically given in Figure 2. Its source code is developed in Fortran 95, and it accounts for the missing values in the data. A test based on the index, namely the accuracy or proportion of correct predictions (Murphy, 1996; Livezey, 2003), was applied for measuring the performance of the logistic models. This test is commonly used to evaluate the performance of weather forecasting in meteorology.

The drought and wet classes of 12-month SPI values are calculated from the observed precipitation values as a first stage. The probability density function (PDF) of precipitation values is the first step to estimate SPI values (one may refer to Türkeş and Tatli [2009] for a discussion on SPIs and modified-SPIs). The gamma function approach is widely

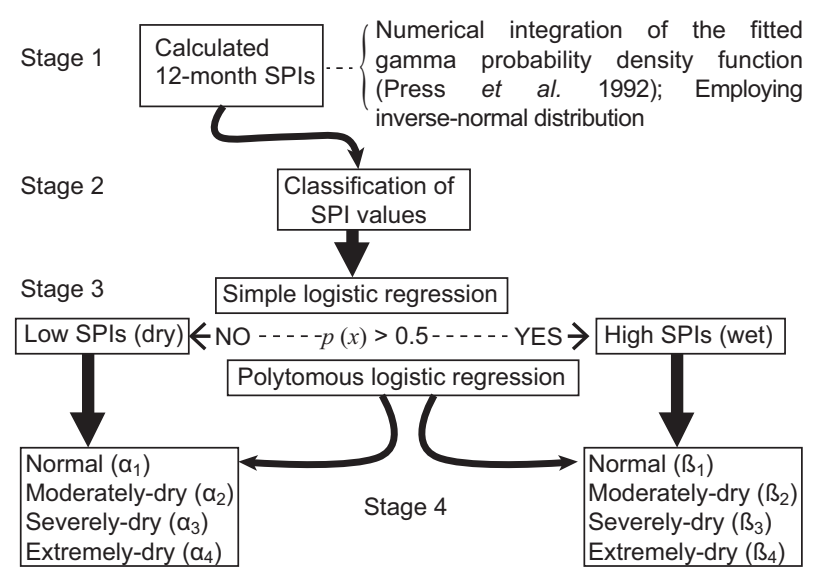

Fig. 2. Schematic description of the suggested downscaling model based on polytomous logistic regression. Alpha and beta vectors shown in parentheses are the coefficients of the regression model in question. used to estimate the PDF of precipitation values (e.g., Thom, 1966; McKee et al., 1993, 1995; Wilks, 1995; Guttman, 1998, 1999). In this study the cumulative distribution function (CDF) of the precipitation series is estimated by the numerical integration of fitted gamma PDF by the incomplete-gamma approach (Press et al., 1992). Twelve-month SPI values are used, but the suggested algorithm can be easily applied to other time slices of the SPI values, such as 1 , $3,6, \ldots$, -month, or more. The gamma PDF and CDF can be written as follows:

$$
\left.\begin{array}{l}
P D F=f(y)=\frac{(y / \beta)^{\alpha-1} \exp (-y / \beta)}{\beta \Gamma(\alpha)}, y, \alpha, \beta>0 \\
C D F=F(y)=\frac{1}{\beta \Gamma(\alpha)} \int_{0}^{y} y^{\alpha-1} \exp (-y / \beta) d y
\end{array}\right\}
$$

where $y$ indicates the precipitation value, and $\alpha$ and $\beta$ are the shape parameter and the scale parameter of the distribution, respectively. The quantity $\Gamma(\cdot)$ is the gamma function defined by

$\Gamma(\alpha)=\int_{0}^{\infty} t^{\alpha-1} e^{-t} d t$

An improved method suggested by Bowman and Shenton (1988) was applied for estimating the shape parameter resulting from the use of an iterative sixth order polynomial. The scale parameter is then calculated by dividing the long-term mean of precipitation values by the shape parameter, $\beta=\bar{y} / \alpha$.

At the second stage, SPI values are classified according to Table II. At the third stage, the dichotomous classes of drought and wet conditions are grouped into two classes, namely high and low SPIs treated as binary values (ones and zeros) represented by wet and dry classes in Figure 2. This stage involves

Table II. Classification of the standardized precipitation index (SPI).

\begin{tabular}{cl}
\hline SPI values & Drought class \\
\hline$\geq 2$ & Extremely wet \\
$1.5-1.99$ & Very wet \\
$1-1.49$ & Moderately wet \\
$-0.99-0.99$ & Near-normal \\
$-1-1.49$ & Moderately dry \\
$-1.5-1.99$ & Severely dry \\
$\leq 2$ & Extremely dry \\
\hline
\end{tabular}


a simple logistic regression which classifies the occurrence probabilities of wet and dry cases.

Finally, the fourth stage involves a polytomous logistic regression. In Figure 2, the vectors given in the parentheses represented by alphas and betas indicate the coefficients of the specific logistic regression. The dependent variable can take four dichotomous values numbered as $(k=0,1,2,3)$, representing the drought classes as shown on the left and right sides of Figure 2. To further clarify this step, assume we wish to estimate the occurrence probability of a moderately dry class. By applying the vector of coefficients, the occurrence probabilities are calculated as:

$P_{2}(x)=\frac{\exp \left(\alpha_{2}^{T} x\right)}{\sum_{i=}^{4} \exp \left(\alpha_{i}^{T} x\right)}$

where $P_{2}(x)$ represents the occurrence probability of a moderately dry class (the subscript 2 indicates the second drought class), and the vector $x$ illustrates the large-scale precipitation series simulated by CGCM2 in surrounding grid points to compare with non-uniformly distributed station data.

After calculating the occurrence probabilities of the entire dry classes by using Eq. 6, the drought class of maximum probability is selected as the downscaled-class for the specific station.

In order to measure the performance of the suggested model, the index of forecast accuracy or proportion of correct predictions (PC) was calculated between the output of the downscaling model-based control and the observed SPI classes for the period 1970-2000. For verifying multi-category forecasts, the method starts with frequencies of the forecast and observations in various bins, as given in Table III. A perfect forecast system should have values of non-zero elements only along the diagonal, and values of 0 (zero) for all entries off the diagonal. The off-diagonal elements give information about the specific nature of the forecast errors (Murphy, 1996; Livezey, 2003). The value of $P C$ for the selected station is calculated as:

$P C=\frac{1}{n} \sum_{i}^{k} n_{i i}, \mathrm{k}=1,2, \ldots, 7$

$P C$ ranges from 0 to 1 . If it assumes a value, close to 1 , this indicates a high forecasting performance.

\section{Discussion and results}

The performance and results of the suggested downscaling models are compared with SPI values obtained from the observed precipitation series by covering each of the dry and wet event classes for the 12-month SPIs calculated over Turkey. The performance of the suggested downscaling model based on the values of $P C$ is given in Figure 3. As shown in this figure, seven drought classes are first transformed into three major drought classes; for example, "extremely wet, very wet and moderately wet" drought classes are merged and renamed as above normal. Likewise, "extremely dry, severely dry and moderately dry" classes are merged, and renamed as below normal. The spatial patterns of the long-term (climatological) occurrence probabilities are shown in Figure 4 and those extracted from the downscaling model are given in Figures 5 through 7 .

Table III. Contingency table of the multi-categories of SPI values. The frequencies are used to calculate the proportion of correct (PC) prediction values as a criterion of performance for the suggested downscaling models.

\begin{tabular}{|c|c|c|c|c|c|c|c|c|c|}
\hline & \multirow[b]{2}{*}{$\mathrm{i}, \mathrm{j}$} & \multicolumn{7}{|c|}{ Observed category } & \multirow[b]{2}{*}{ Total } \\
\hline & & $\begin{array}{c}\text { Extremely } \\
\text { dry }\end{array}$ & $\begin{array}{c}\text { Severely } \\
\text { dry }\end{array}$ & $\begin{array}{c}\text { Moderately } \\
\text { dry }\end{array}$ & Normal & $\begin{array}{c}\text { Moderately } \\
\text { wet }\end{array}$ & $\begin{array}{l}\text { Very } \\
\text { wet }\end{array}$ & $\begin{array}{c}\text { Extremely } \\
\text { wet }\end{array}$ & \\
\hline \multirow{8}{*}{ 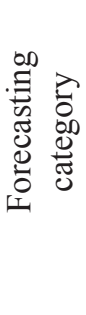 } & \multirow{8}{*}{$\begin{array}{l}\text { Extremely dry } \\
\text { Severely dry } \\
\text { Moderately dry } \\
\text { Normal } \\
\text { Moderately wet } \\
\text { Very wet } \\
\text { Extremely wet } \\
\text { Total }\end{array}$} & $\mathrm{n}_{11}$ & $\mathrm{n}_{12}$ & $\mathrm{n}_{13}$ & $\mathrm{n}_{14}$ & $\mathrm{n}_{15}$ & $\mathrm{n}_{16}$ & $\mathrm{n}_{17}$ & $\mathrm{n}_{1}$ \\
\hline & & $\mathrm{n}_{21}$ & $\mathrm{n}_{22}$ & $\mathrm{n}_{23}$ & $\mathrm{n}_{24}$ & $\mathrm{n}_{25}$ & $\mathrm{n}_{26}$ & $\mathrm{n}_{27}$ & $\mathrm{n}_{2}$ \\
\hline & & $n_{31}$ & $n_{32}$ & $n_{33}$ & $\mathrm{n}_{34}$ & $\mathrm{n}_{35}$ & $\mathrm{n}_{36}$ & $\mathrm{n}_{37}$ & $\mathrm{n}_{3}$ \\
\hline & & $\mathrm{n}_{41}$ & $\mathrm{n}_{42}$ & $\mathrm{n}_{43}$ & $\mathrm{n}_{44}$ & $\mathrm{n}_{45}$ & $\mathrm{n}_{46}$ & $\mathrm{n}_{47}$ & $\mathrm{n}_{4}$ \\
\hline & & $\mathrm{n}_{51}$ & $\mathrm{n}_{52}$ & $\mathrm{n}_{53}$ & $\mathrm{n}_{54}$ & $\mathrm{n}_{55}$ & $\mathrm{n}_{56}$ & $\mathrm{n}_{57}$ & $\mathrm{n}_{5}$ \\
\hline & & $\mathrm{n}_{61}$ & $\mathrm{n}_{62}$ & $\mathrm{n}_{63}$ & $\mathrm{n}_{64}$ & $\mathrm{n}_{65}$ & $\mathrm{n}_{66}$ & $\mathrm{n}_{67}$ & $\mathrm{n}_{6}$ \\
\hline & & $\mathrm{n}_{71}$ & $\mathrm{n}_{72}$ & $\mathrm{n}_{73}$ & $\mathrm{n}_{74}$ & $\mathrm{n}_{75}$ & $\mathrm{n}_{76}$ & $\mathrm{n}_{77}$ & $\mathrm{n}_{7}$ \\
\hline & & $\mathrm{n}_{.1}$ & $\mathrm{n}_{.2}$ & $\mathrm{n}_{.3}$ & $\mathrm{n}_{.4}$ & $\mathrm{n}_{.5}$ & $\mathrm{n}_{.6}$ & $\mathrm{n}_{.7}$ & $\mathrm{n}$ \\
\hline
\end{tabular}


(a)

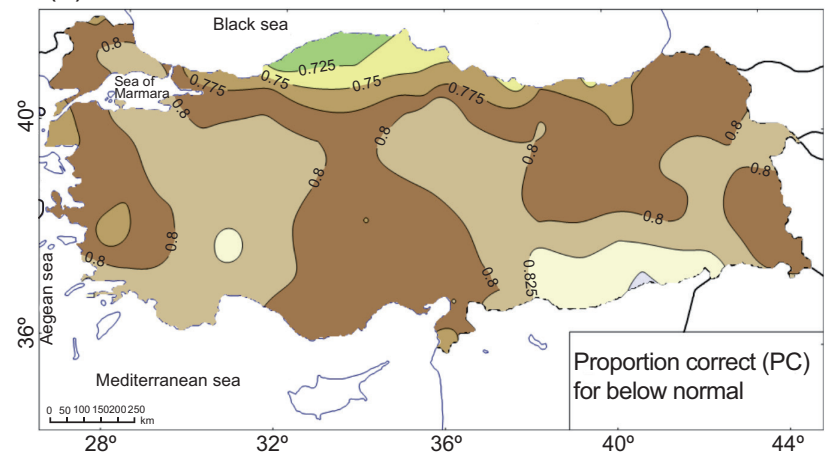

(c)

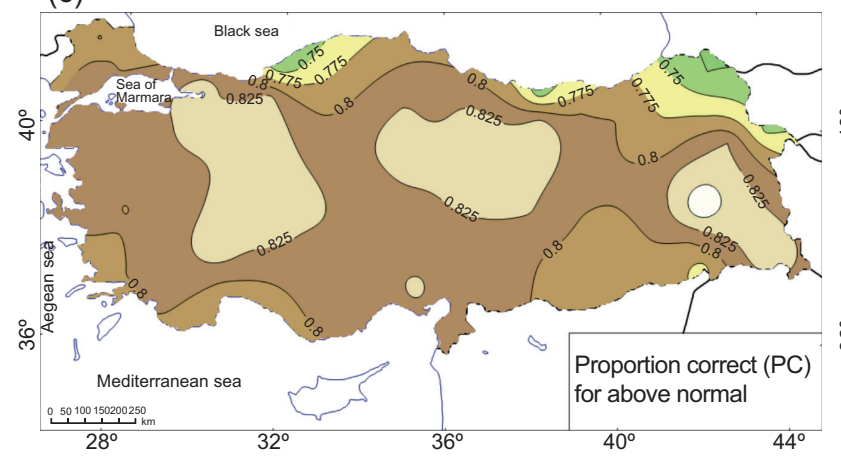

(b)

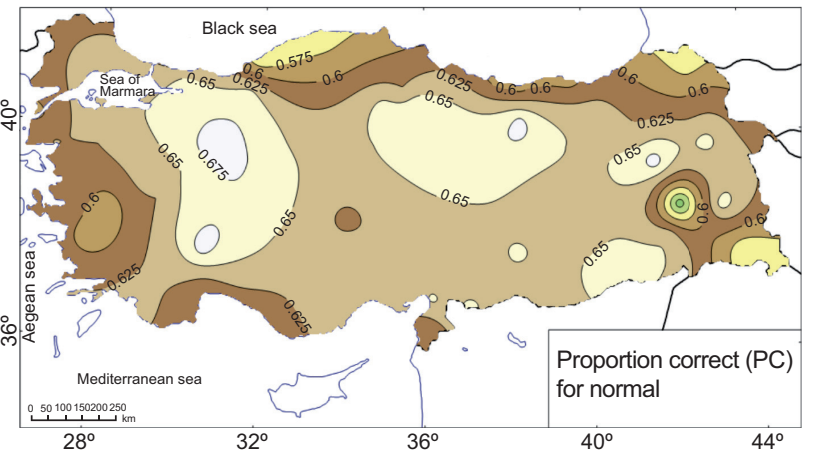

(d)

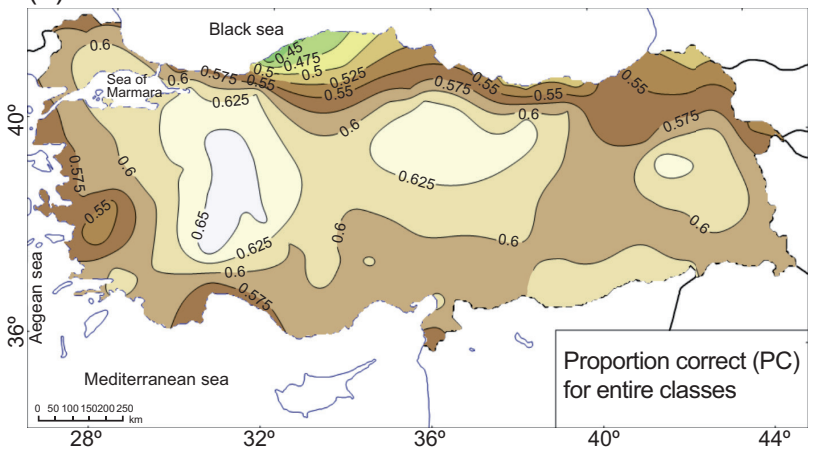

Fig. 3. Spatial distribution of the proportion of correct (PC) prediction values obtained by comparing the downscaling-model of the IPCC control scenario and observations. For more information, please refer to the text.

The level of long-term probabilities of downscaled drought classes generally shows a zonal gradient from the rainfall regimes of the Mediterranean to the Black Sea basins. Maximum probabilities of a dry class regime are found near the border of Syria-Turkey, where the warmest and driest land of Turkey is located (Tatli and Türkeş, 2011). The results of downscaled drought classes and their relationships with the synoptic-climatological situations are discussed in the following sub-sections.

\subsection{Extremely dry conditions and projections}

According to the extremely $d r y$ conditions obtained from the observed rainfall totals, the long-term (climatological) probabilities display a zonal-pattern gradient from the Mediterranean to the Black Sea basins. Maximum probabilities are found in the warm and dry southern parts of the continental Mediterranean (CMED) rainfall regions, in which the areas of the Turkish-Syrian border are located (Fig. 4a).

According to the logistic model constructed by the predictors from the control climate simulations (Fig. 5a), the probabilities of extremely dry conditions will increase in approximately $10 \%$ of the cases.
These downscaling results for the Mediterranean (MED) and CMED rainfall regions agree well with the observations, as seen in Figure 4a. The probabilities of extremely dry conditions obtained from the observed values are around $1 \%$, in spite of the results of the logistic model based on the control scenario indicate around $20 \%$ in the country's sub-regions of the western Black Sea basin (Fig. 5a). Additionally, the results show that the probabilities do not change sharply in the regions of the Marmara Transition (MRT) and the Mediterranean Transition (MEDT).

The probability patterns of downscaling models based on the IPCC SRESS A2 and B2 (Figs. 6 and 7, respectively) resemble each other. Furthermore, the estimated probabilities of extremely dry conditions in the Black Sea (BLS) region seem similar to the probabilities obtained by the downscaling-model based on the control simulations. However, the estimated probabilities of extremely dry conditions in the MED and CMED regions are $10 \%$ higher than the values obtained from the control simulation (Figs. 6a and 7a). The estimated probabilities for the eastern sub-regions of the BLS and northeastern Anatolia are similar in magnitude and spatial distribution. 
(a)

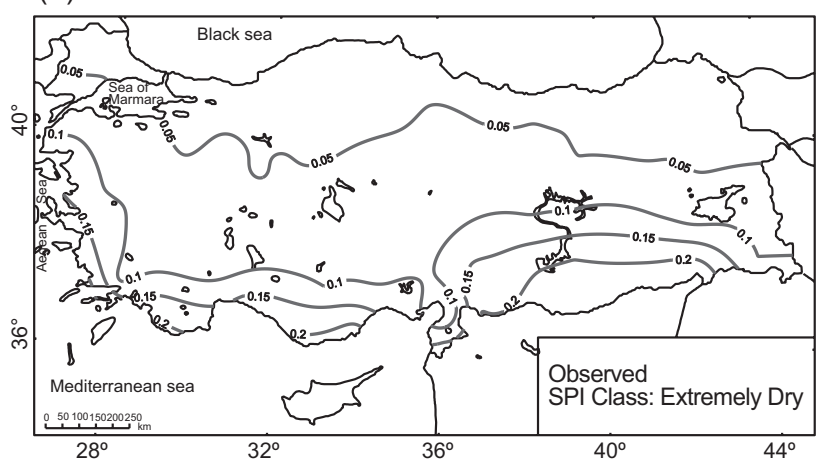

(c)

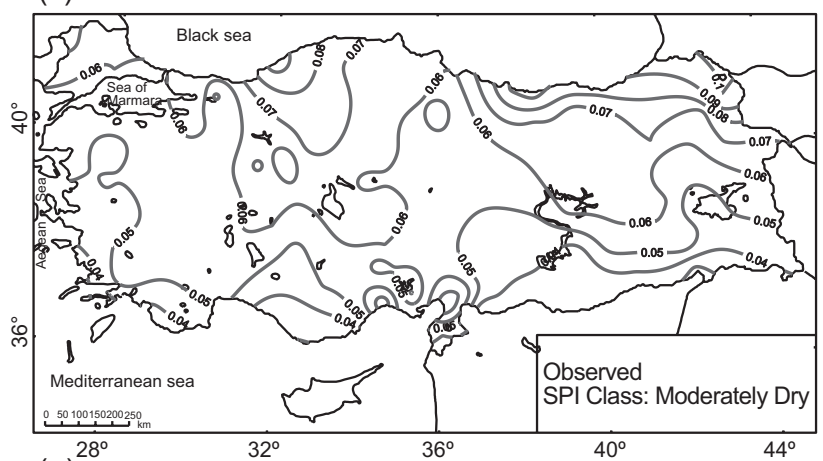

(b)

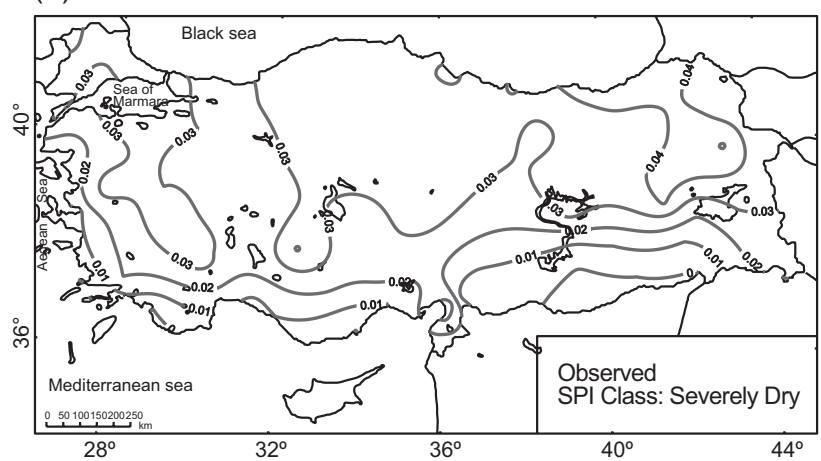

(d)

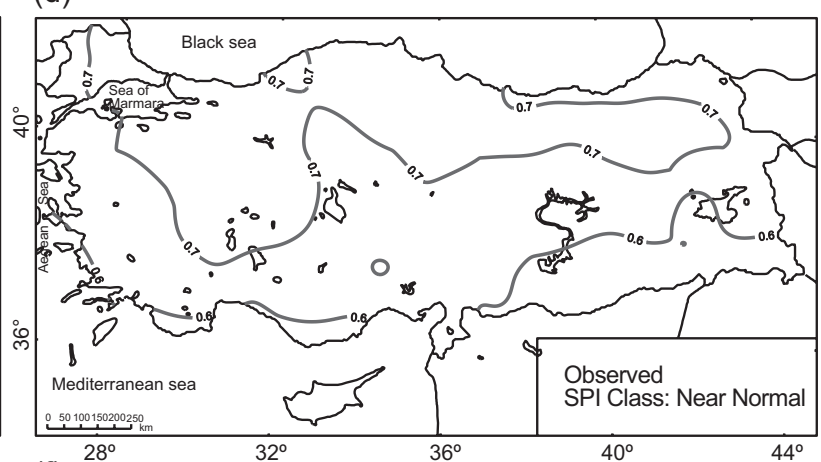

(f)

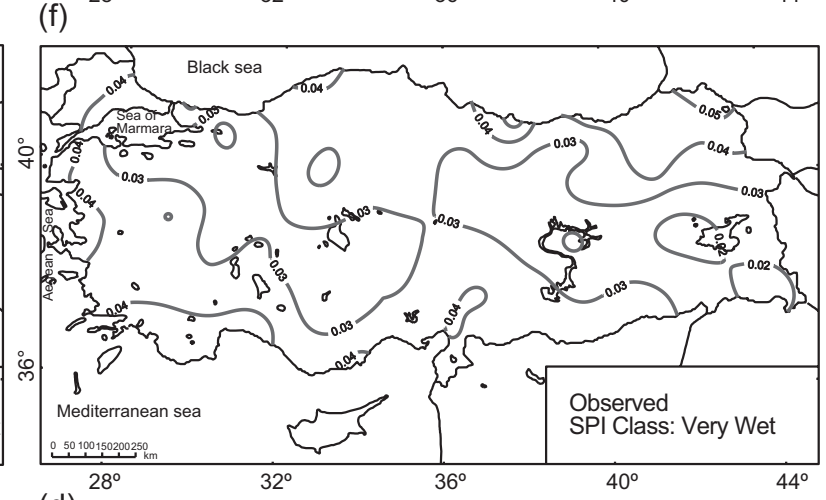

(d)
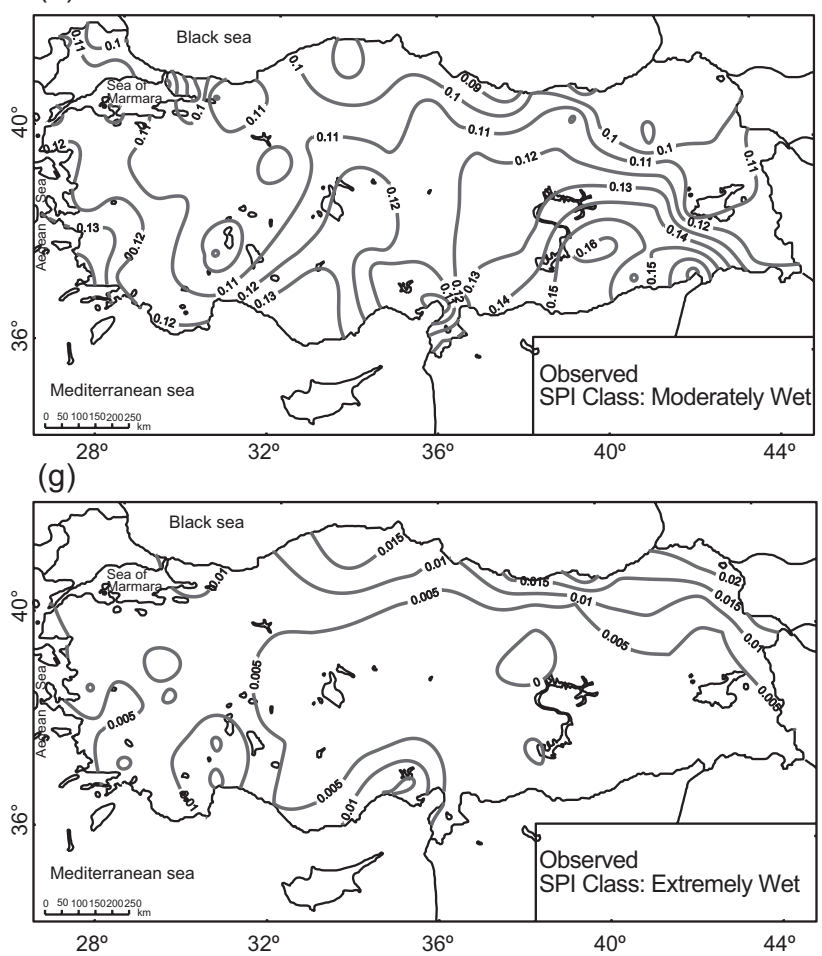
(a)

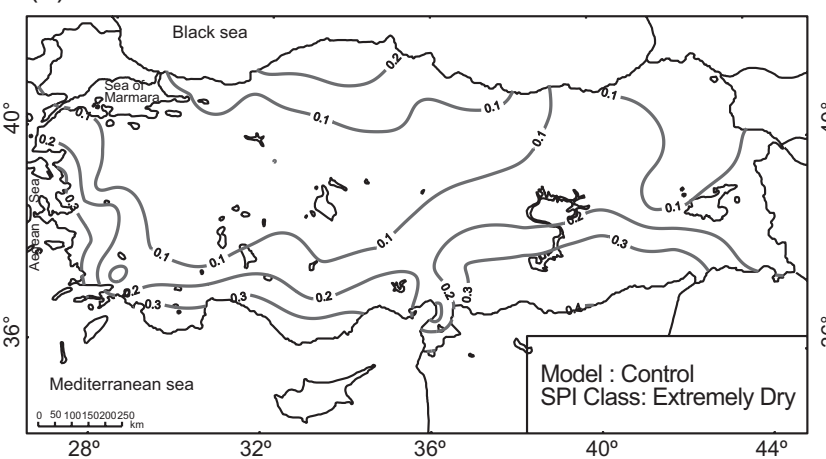

(c)

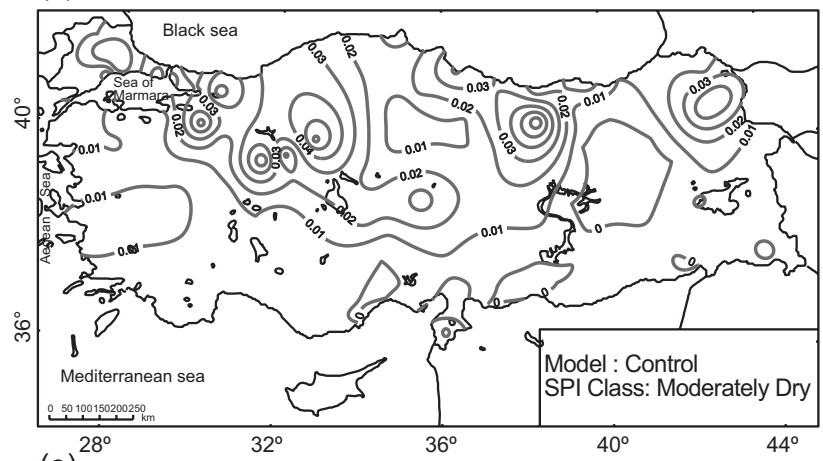

(e)

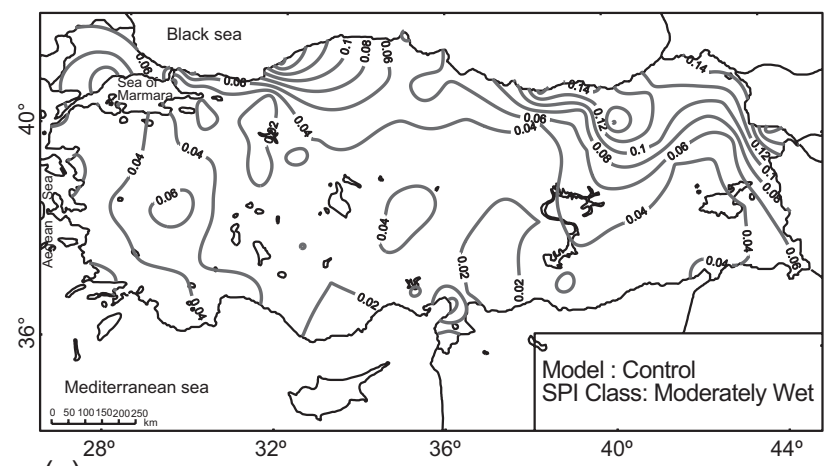

(g)

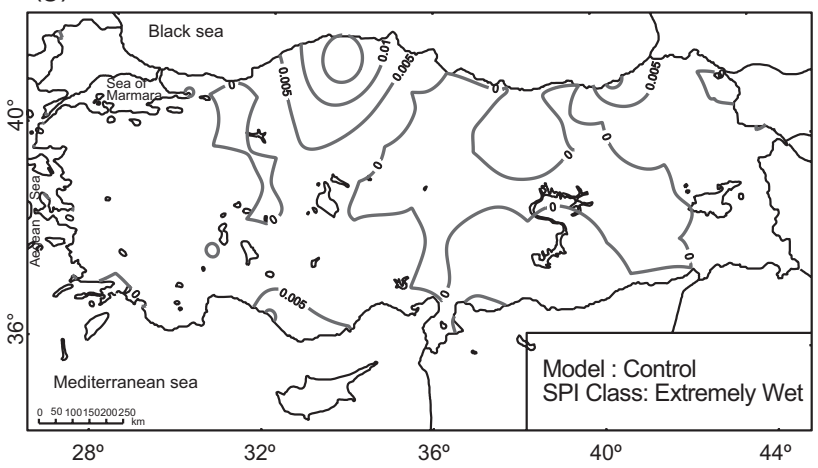

(b)

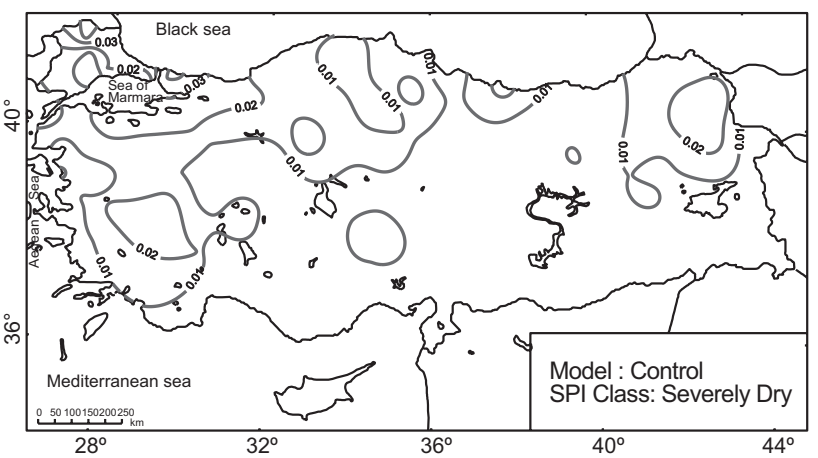

(d)

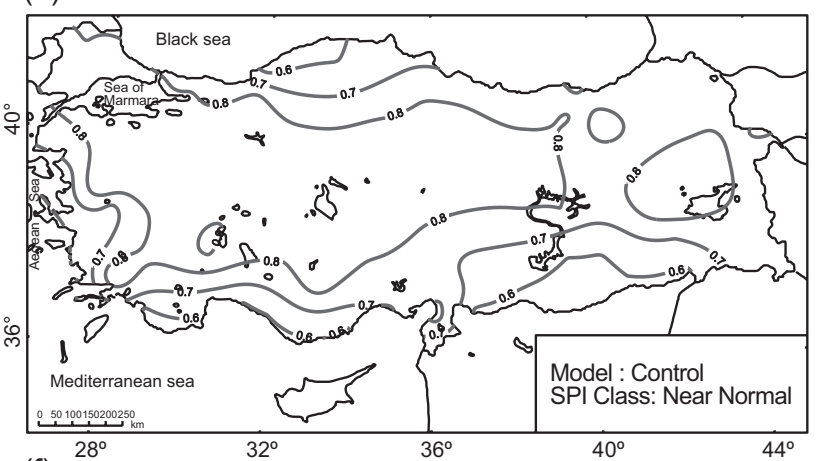

(f)

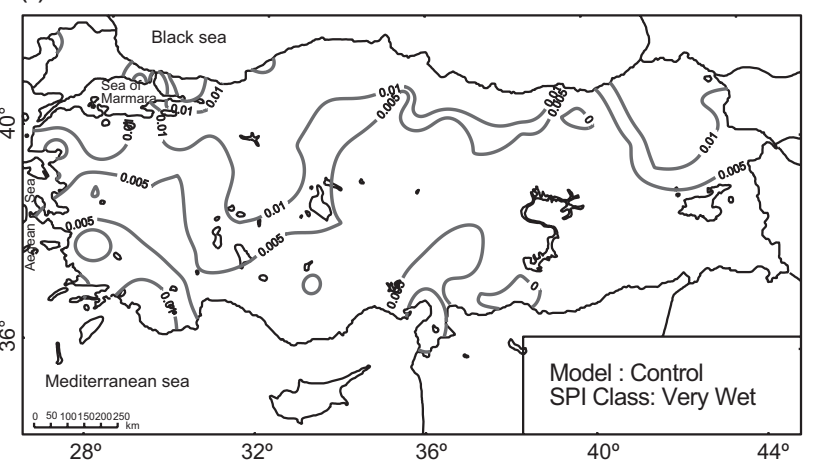

Fig. 5. Spatial distribution of the long-term probabilities of SPIs obtained from the suggested logistic downscaling model based on the control scenario. 
(a)

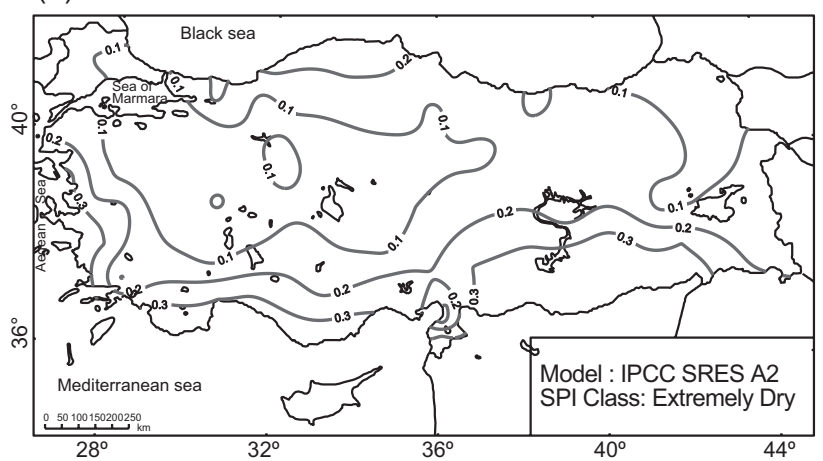

(c)

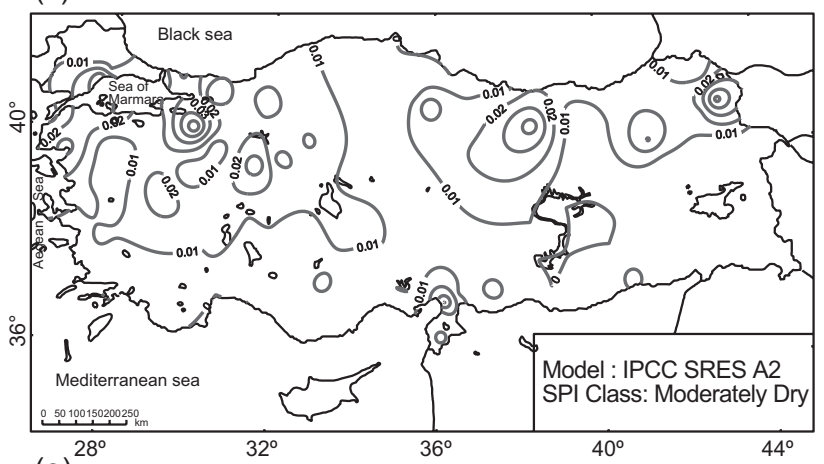

(b)

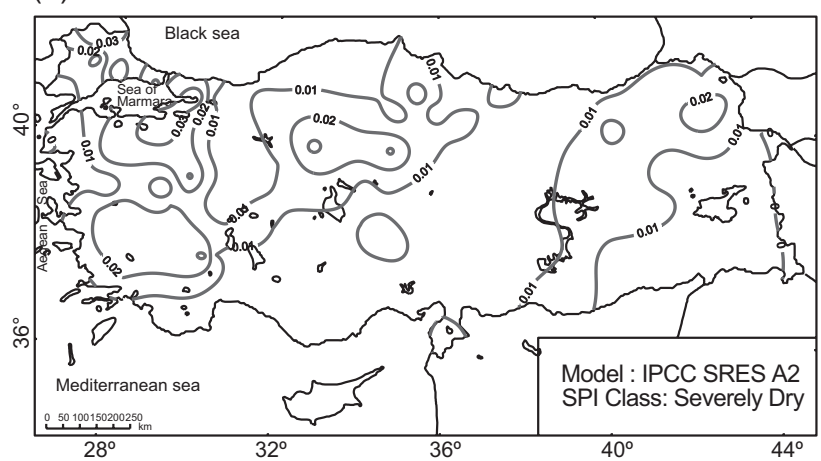

(d)

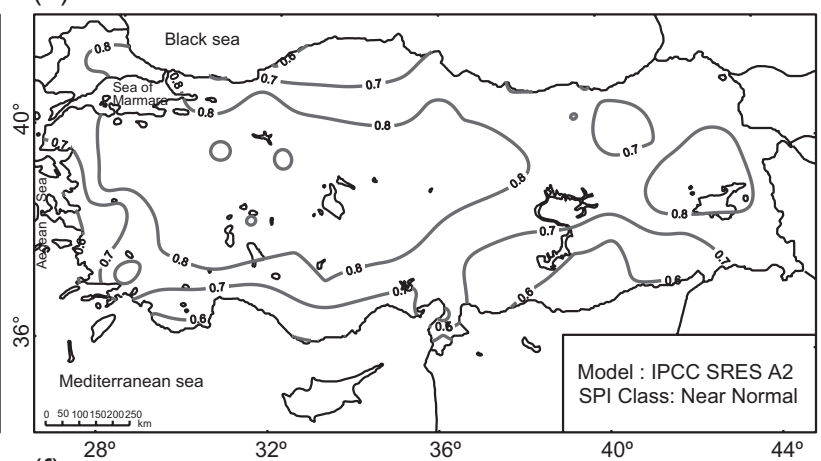

(f)

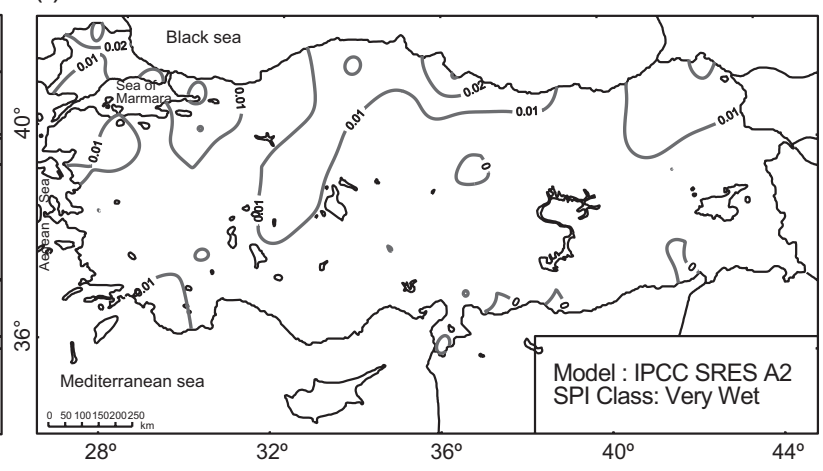

(g)
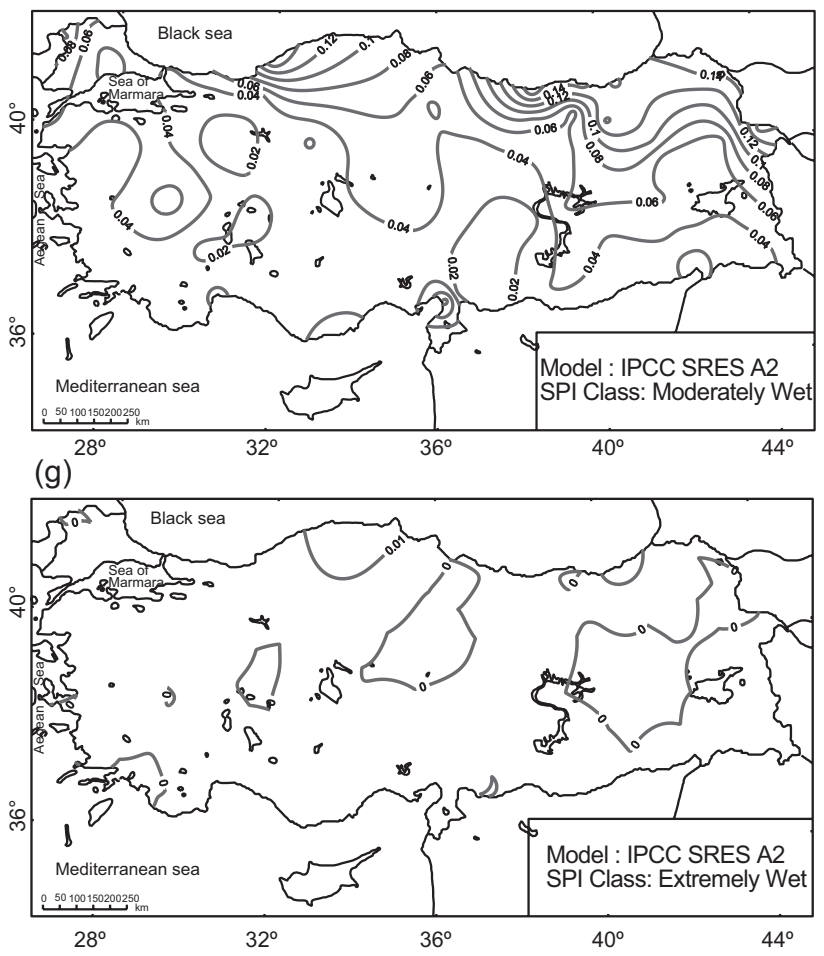

Fig. 6. Spatial distribution of the long-term probabilities of SPIs of the downscaling model based on the IPCC SRES A2. 
(a)

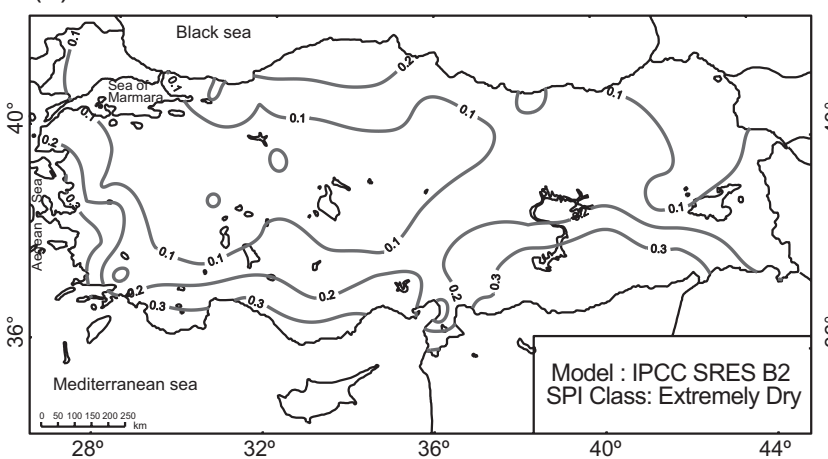

(c)

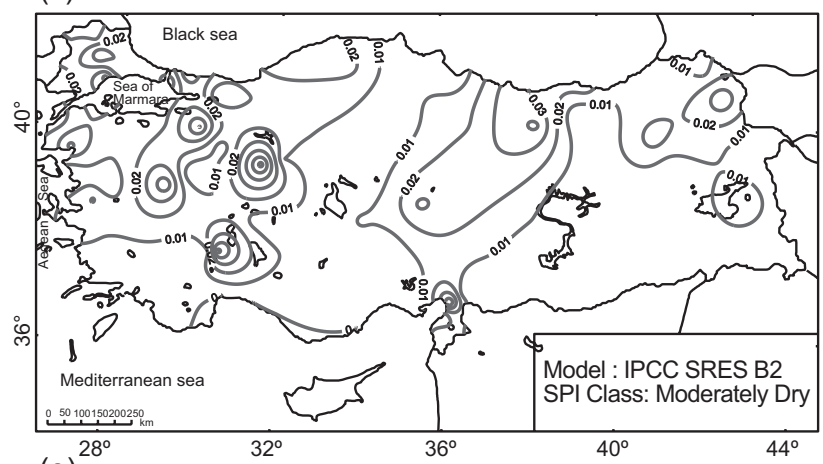

(e)

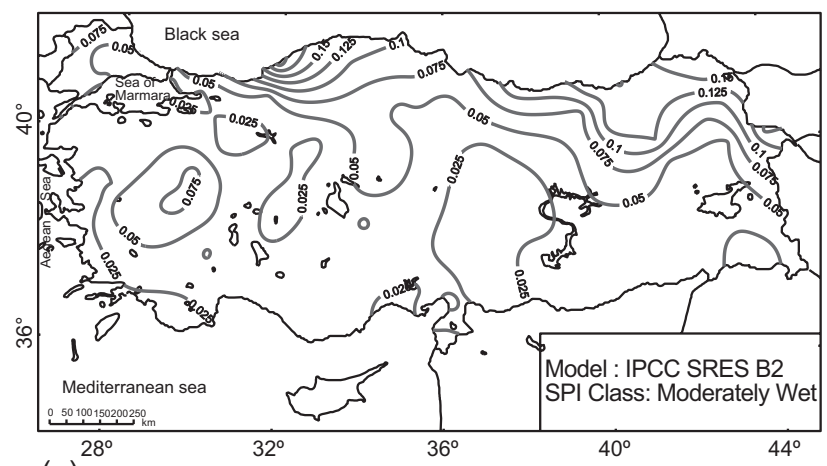

(g) 28

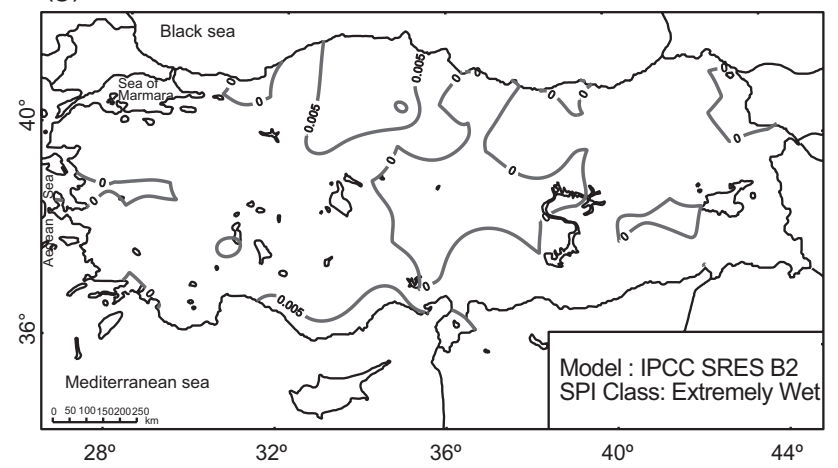

(b)

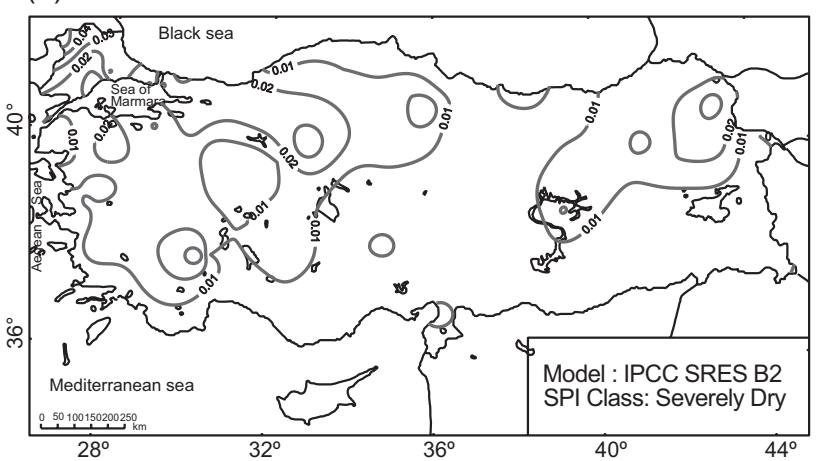

(d)

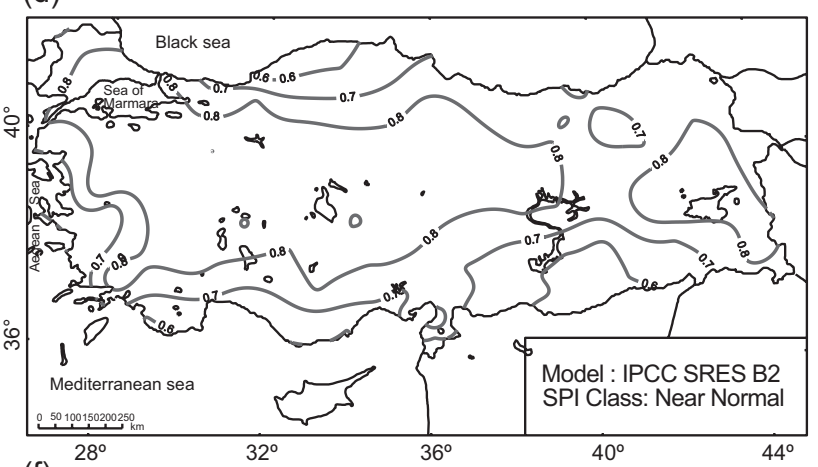

(f)

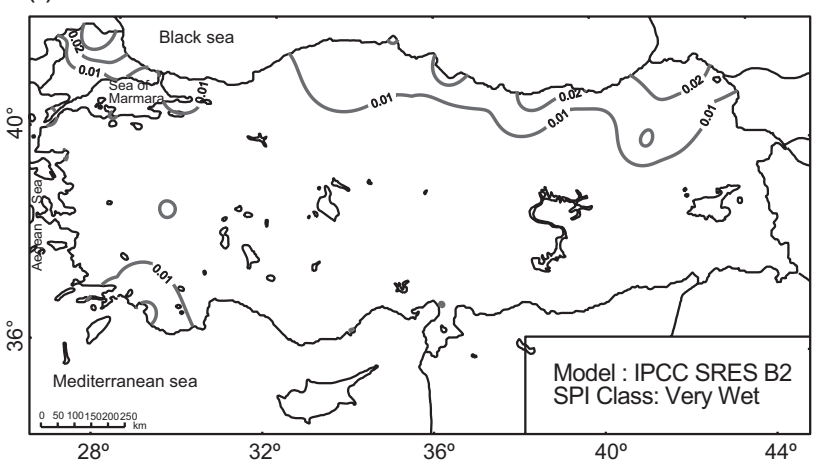

Fig. 7. Spatial distribution of the long-term probabilities of SPIs of the downscaling model based on the IPCC SRES B2. 


\subsection{Severely dry conditions and projections}

Although the observed probabilities of severely $d r y$ conditions are relatively low (about $2 \%$ ), they increase from the MED and CMED to the northern part of the country. Furthermore, the probability values reach $4 \%$ in the eastern BLS and northern Anatolia sub-regions of the Anatolian Peninsula, even though the probability values of extremely dry conditions are low (Fig. 4b).

The logistic control model produces somewhat different patterns of probabilities when compared to observations, except for the MRT rainfall region (Fig. $5 b)$. Conversely, results of the logistic model based on the IPCC SRES A2 and B2 scenarios show patterns similar to the observed probabilities obtained from the severely dry scenario (Figs. $6 \mathrm{~b}$ and $7 \mathrm{~b}$ ).

The probabilities of a severely dry scenario obtained from the observations have a $2-4 \%$ interval, with some exceptions as seen in the MED and CMED rainfall regions (Fig. 4b), where the probabilities of a severely dry scenario show a negative trend. The results of the logistic model based on the IPCC SRES A2 have somewhat higher probabilities than those obtained from the IPCC SRES B2 (Figs. $6 \mathrm{~b}$ and 7b).

\subsection{Moderately dry conditions and projections}

The probabilities of having 12-month SPI values of moderately dry class increase in rainfall regions MED and BLS, where the probabilities observed are about $4-5 \%$ (Fig. 4c). The probabilities observed in the western and eastern BLS sub-regions vary from 7 to $9 \%$, respectively.

The results of the logistic model based on the control scenario show that the pattern of higher probabilities has detailed spatial features, though some small probabilities are also observed (Fig. 5c). According to the logistic model with predictors from the IPCC SRES A2 and B2 scenarios, the patterns of probabilities of moderately dry conditions have a positive trend (Figs. $6 \mathrm{c}$ and $7 \mathrm{c}$ ).

\subsection{Normal conditions and projections}

The 12-month SPI values from observations in Turkey are mostly in the near normal class, since the climatological probabilities are generally changing from 60 to $70 \%$ (Fig. 4d). As a result, this class could be referred to as reference class, which has a probability of being observed at least in $60 \%$ of the meteorological stations.
The probabilities of the logistic model based on the control scenario are in the near normal class, partially decreasing in the BLS basin. However, the patterns show that probabilities increase in the regions of the MRT and continental eastern Anatolia (CEAN) (Fig. 5d), where the probabilities observed are around $80 \%$ or more.

The results obtained from the logistic model based on the IPCC SRES A2 and B2 scenarios are significantly similar, and related to the results obtained from the control scenario (Figs. 6d and 7d). According to the downscaling results, it can be expected that the near normal class probability will increase about $10 \%$ as compared to its present values.

\subsection{Moderately wet conditions and projections}

In Figure $4 \mathrm{e}$, the probabilities of moderately wet conditions have a negative gradient from the sub-rainfall regions of MED, MEDT and CMED to the BLS basin. Some of the minimum probabilities are observed on the coasts of the BLS basin, whereas the maximum values are only obtained in the CMED regions. The sub-regions of western and eastern BLS and CEAN are exceptions, since the logistic model based on the control scenario simulates very small probabilities of moderately wet conditions (Fig. 6e). The maximum probabilities are generally observed in the rainfall regimes of the MED and CMED, whereas the probabilities of the logistic model based on the control scenario decrease here and increase in the eastern BLS basin and north-eastern Anatolia.

The results of the logistic model based on the IPCC SRES A2 and B2 show similarities with the control scenario (Figs. 6e and 7e). These similarities may be seen in the probability patterns of moderately wet conditions, which decrease in the southern and western regions of the country.

Accordingly, it can be expected that the probabilities of moderately wet conditions will increase in the BLS basin and in the northeastern continental regions of the country. Furthermore, the maximum probabilities of moderately wet conditions are found in the eastern BLS basin for the logistic model based on the IPCC SRES A2, and in northeastern Anatolia for the model based on the IPCC SRES B2.

\subsection{Very wet conditions and projections}

The probabilities of the very wet class range from $3 \%$ in the CEAN region to $4 \%$ in the Aegean, Mediterranean 
and Black Sea regions (Fig. 4f). The maximum probabilities of very wet conditions are about $5 \%$ in northeastern Anatolia. The probabilities are smaller for the logistic model based on the control scenario (Fig. 5f). The probabilities in the Black Sea basin, middle-northern parts of the CCAN and northeastern Anatolia are nearly $1 \%$ and close to $0 \%$ for the rest of the country.

The results obtained from logistic models based on the IPCC SRES A2 and B2 are consistent with the control simulations, in which the probabilities of very wet conditions are expected to be below $1 \%$ in the majority of the country (Figs. $6 \mathrm{f}$ and $7 \mathrm{f}$ ). Both models show that the maximum probabilities are seen in parts of the northern Thrace, and in the sub-regions of the eastern and middle Black sea basin.

\subsection{Extremely wet conditions and projections}

The probabilities of extremely wet conditions from observations are small in magnitude and vary from 0 to $2 \%$. Maximum probabilities are evident over some limited areas of the eastern Black Sea basin, northeastern Anatolia and western Mediterranean coasts (Fig. 4g). According to the results of the logistic model based on the control scenario, except in the sub-regions of the western Black Sea basin, the probabilities are very small (Fig. $5 \mathrm{~g}$ ). In addition, the results of logistic models based on the IPCC SRES A2 and B2 agree with the results of the logistic model based on the control scenario, indicating that in the future, probabilities of extremely wet conditions will decrease in the entire country (Figs. $6 \mathrm{~g}$ and $7 \mathrm{~g}$ ).

\section{Conclusions}

Climate change impacts on future weather and climate are traditionally evaluated by running general circulation models in the various socio-economic scenarios. However, simulations of the GCMs at coarse grids may yield large uncertainties in climate variables. For instance, changes in global climate give rise to large uncertainties when determining its impacts on regional precipitation regimes, such as drought and wet conditions and their variability (Tatli, 2014). Downscaling techniques can provide an answer to these problems.

At country level, downscaling drought and wet conditions is a very important challenge, especially in management plans of water resources, energy, natural disasters, agriculture and forestry. Drought conditions often cause serious damage and negatively affect various socio-economical activities. For example, they can lead to decreased crop yields and reduced fresh water resources.

Traditionally, downscaled precipitation is used to estimate the SPI. However, it is easier to downscale the drought classes than precipitation itself. In addition, one may employ much more sophisticated downscaling processes for selecting the appropriate predictors (e.g., Tatli et al., 2004; Pryor et al., 2005; Tatli, 2007, 2013).

Since the downscaling model based on logistic regression suggested in this study uses the largescale predictors directly from the GCMs, it should be regarded as model output statistics.

In this study, the risks of drought and extreme wet conditions under climate change scenarios are assessed by means of statistical downscaling. According to the logistic models applied, the results are more sensitive to the predictors obtained from largescale GCMs, while boundary conditions coming from these are sensitive, as in the dynamical-downscaling procedure. The applied logistic models produce satisfactory statistical results when compared with observations. The probabilistic patterns of the results are statistically acceptable, since they capture the main features of the local-scale climate. Since the main goal of downscaling is to determine the effects of large-scale climatic changes on the local-scale variables, the proposed model based on logistic regression produces acceptable statistical results.

Additionally, the results reveal that the downscaled-probabilities of very wet and extremely wet conditions will decrease in the future for almost all three scenarios. However, there are some exceptions. In the future, the probabilities of near-normal conditions will decrease in the BLS basin and relatively increase in rainfall regions of the MRT and CEAN.

\section{Acknowledgments}

The author acknowledges the anonymous referees for their valuable and constructive suggestions.

\section{References}

Aldrich J. H. and F. D. Nelson, 1984. Linear probability, logit, and probit models. Sage, Beverly Hills, Ca, 96 pp.

Anandhi A., V. V. Srinivas, R. S. Nanjundiah and D. N. Kumar, 2008. Downscaling precipitation to river basin 
in India for IPCC SRES scenarios using support vector machine. Int. J. Climatol. 28, 401-420.

Bowman K. O. and L. R. Shenton, 1988. Properties of estimators for the gamma distribution. Marcel Dekker, New York, 269 pp.

Conway D. and P. D. Jones, 1998. The use of weather types and air flow indices for GCM downscaling. $J$. Hydrometeorol. 212-213, 348-361.

Coulibaly P., Y. B. Dibike and F. Anctil, 2005. Downscaling precipitation and temperature with temporal neural networks. J. Hydrometeorol. 6, 483-496.

Dibike Y. B. and P. Coulibaly, 2006. Temporal neural networks for downscaling climate variability and extremes. Neural Networks 19, 135-144.

Easterling D. R., 1999. Development of regional climate scenarios using a downscaling approach. Climatic Change 41, 615-634.

Flato G. M., G. J. Boer, W. G. Lee, N. A. McFarlane, D. Ramsden, M. C. Reader and A. J. Weaver, 2000. The Canadian Centre for Climate Modelling and analysis global coupled model and its climate. Clim. Dyna. 16, 451-467.

Fowler H. J., S. Blenkinsop and C. Tebaldi, 2007. Linking climate change modeling to impacts studies: Recent advances in downscaling techniques for hydrological modeling. Int. J. Climatol. 27, 1547-1578.

Guttman N. B., 1998. Comparing the Palmer drought index and the standardized precipitation index. J. Am. Water. Resour. As. 34,113-121.

Guttman N. B., 1999. Accepting the standardized precipitation index: a calculation algorithm. J. Am. Water. Resour. As. 35, 311-322.

Hay L. E. and M. P. Clark, 2003. Use of statistically and dynamically downscaled atmospheric model output for hydrologic simulations in three mountainous basins in the western United States. J. Hydrol. 282, 56-75.

Hayes M. J., M. D. Svoboda, D. A. Wilhite and O. V. Vanyarkho, 1999. Monitoring the 1996 drought using the standardized precipitation index. B. Am. Meteorol. Soc. 80, 429-438.

Hertig E. and J. Jacobeit, 2008. Downscaling future climate change: Temperature scenarios for the Mediterranean area. Glob. Plan. Change 63, 127-131

Huth R., J. Kysely and L. Pokorna, 2000. A GCM simulation of heat waves, dry spells, and their relationships to circulation. Climatic Change 46, 29-60.

IPCC, 2000. Special report on emissions scenarios. A special report of Working Group III of the Intergovernmental Panel on Climate Change (N. Nakicenovic, J.
Alcamo, G. Davis, B. de Vries, J. Fenhann, S. Gaffin, K. Gregory, A. Griibler, T. Yong Jung, T. Kram, E. Lebre La Rovere, L. Michaelis, S. Mori, T. Morita, W. Pepper, H. Pitcher, L. Price, K. Riahi, A. Roehrl, H. Holger Rogner, A. Sankovski, M. Schlesinger, P. Shukla, S. Smith, R. Swart, S. van Rooijen, N. Victor and Z. Dadi, Eds.). Cambridge University Press, 599 pp. IPCC, 2001. Climate Change 2001: The Scientific Basis. Contribution of Working Group I to the Third Assessment Report of the Intergovernmental Panel on Climate Change (J. T. Houghton, Y. Ding, D. J. Griggs, M. Noguer, P. J. van der Linden, X. Dai, K. Maskell, and C. A. Johnson, Eds.). Cambridge University Press, $881 \mathrm{pp}$.

IPCC, 2007. Climate change 2007: The physical science basis. Contribution of Working Group I to the Fourth Assessment Report of the Intergovernmental Panel on Climate Change (S. Solomon, D. Qin, M. Manning, Z. Chen, M. Marquis, K. B. Averyt, M. Tignor and H. L. Miller, Eds.). Cambridge University Press, 996 pp. Karl T. R., W. C. Wang, M. E. Schlesinger, R. W. Knight and D. Portman, 1990. A method of relating general circulation model simulated climate to the observed local climate. Part I: Seasonal statistics. J. Climate 3, 1053-1079.

Kleinbaum D. G. and M. Klein, 2002. Logistic regression. Springer-Verlag, Berlin, New York, London, 701 pp.

Kocak K., L. Saylan and J. Eitzinger, 2004. Nonlinear prediction of near-surface temperature via univariate and multivariate time series embedding. Ecol. Model. 173, 1-7.

Livezey R. E., 2003. Categorical events. In: Forecast verification: Practitioner's guide in atmospheric science (I. T. Jolliffe and D. B. Stephenson, Eds.). John Wiley and Sons, 77-96.

Loukas A., L. Vasiliades and J. Tzabiras, 2008. Climate change effects on drought severity. Adv. Geosci. 17, 23-29.

Mascaro G., R. Deidda and E. R. Vivoni, 2008. A new verification method to ensure consistent ensemble forecasts through calibrated precipitation downscaling models. Mon. Weather Rev. 136, 3374-3391.

McKee T. B., N. J. Doesken and J. Kleist, 1993. The relationship of drought frequency and duration of time scales. Proceedings of the Eighth Conference on Applied Climatology, American Meteorological Society, Anaheim, Ca, 179-186.

McKee T. B., N. J. Doesken and J. Kleist, 1995. Drought monitoring with multiple time scales. Proceedings of 
the Ninth Conference on Applied Climatology, Dallas, Tx, American Meteorological Society, 233-236.

Menard S., 1995. Applied logistic regression analysis. Sage, Thousand Oaks, Ca, 128 pp.

Mishra A. K., M. Özger and V. P. Singh, 2009. Trend and persistence of precipitation under climate change scenarios for Kansabati basin, India. Hydrol. Process. 23, 2345-2357.

Mishra A. K. and V. P. Singh, 2009. Analysis of drought severity-area-frequency curves using a general circulation model and scenario uncertainty. J. Geophys. Res. 114, D06120, doi:10.1029/2008JD010986.

Murphy A. H., 1996. The Finley affair: A signal event in the history of forecast verification. Weather Forecast. 11, 3-20.

Prasad K., S. K. Dash and U. C. Mohanty, 2010. A logistic regression approach for monthly rainfall forecasts in meteorological subdivisions of India based on DEMETER retrospective forecasts. Int. J. Climatol. 30, 1577-1588.

Preisler H. K. and A. L. Westerling, 2007. Statistical model for forecasting monthly large wildfire events in western United States. J. Appl. Meteorol. Clim. 46, 1020-1030.

Press W. H., B. P. Flannery, S. A. Teukolsky and W. T. Vetterling, 1992. Numerical recipes in FORTRAN: The art of scientific computing, $2^{\text {nd }}$ ed. Cambridge University Press, 1486 pp.

Pryor S. C., J. T. Schoof and R. J. Barthelmie, 2005. Empirical downscaling of wind speed probability distributions. J. Geophys. Res. 110, D19109, doi:10.1029/ 2005JD005899.

Öztürk T., H. Altınsoy, M. Türkeş and M. L. Kurnaz, 2012. Simulation of temperature and precipitation climatology for central Asia CORDEX domain by using RegCM 4.0. Clim. Res. 52, 63-76.

Radu R., M. Deque and S. Somot, 2008. Spectral nudging in a spectral regional climate model. Tellus $A \mathbf{6 0}$, 898-910.

Schmith T., 2008. Stationarity of regression relationships: application to empirical downscaling. J. Climate 21, 4529-4537

Semenov M. A. and E. M. Barrow, 1997. Use of a stochastic weather generator in the development of climate change scenarios. Climatic Change 35, 397-414.

Steinemann A., 2003. Drought indicators and triggers: A stochastic approach to evaluation. J. Am. Water. Resour. As. 39, 1217-1233.

Tabachnick B. G. and L. S. Fidell, 1996. Using multivariate statistics. Harper Collins, New York, 1024 pp.
Tatli H., H. N. Dalfes and S. S. Mentes, 2004. A statistical downscaling method for monthly total precipitation over Turkey. Int. J. Climatol. 24, 161-180.

Tatli H., H. N. Dalfes and S. S. Mentes, 2005. Surface air temperature variability over Turkey and its connection to large-scale upper air circulation via multivariate techniques. Int. J. Climatol. 25, 331-350.

Tatli H., 2007. Synchronization between the North Sea-Caspian pattern (NCP) and surface air temperatures in NCEP. Int. J. Climatol. 27, 1171-1187.

Tatli H. and M. Türkeş, 2011. Empirical orthogonal function analysis of the Palmer drought indices. Agr. Forest. Meteorol. 151, 981-991, doi:10.1016/j.agrformet.2011.03.004.

Tatli H., 2013. Statistical downscaling and applications. Lap Lambert Academic Publishing, Germany.

Tatli H., 2014. Statistical complexity in daily precipitation of NCEP/NCAR reanalysis over the Mediterranean basin. Int. J. Climatol. 34, 155-161.

Thom H. C. S., 1966. Some methods of climatological analysis. World Meteorological Organization, Technical Note No. 81, Geneva, Switzerland.

Timothy D. M. and M. Hulme, 1999. Predicting regional climate change: Living with uncertainty. Prog. Phys. Geog. 23, 57-78.

Tolika K., P. Maheras, M. Vafiadis, H. A. Flocasc and A. Arseni-Papadimitriou, 2007. Simulation of seasonal precipitation and raindays over Greece: A statistical downscaling technique based on artificial neural networks (ANNs). Int. J. Climatol. 27, 861-881.

Türkeş M. and H. Tatli, 2009. Use of the standardized precipitation index (SPI) and a modified SPI for shaping the drought probabilities over Turkey. Int. J. Climatol. 29, 2270-2282.

Türkeş M. and H. Tatli, 2011. Use of the spectral clustering to determine coherent precipitation regions in Turkey for the period 1929-2007. Int. J. Climatol. 31, 2055-2067.

Vasiliades L., A. Loukas and G. Patsonas, 2009. Evaluation of a statistical downscaling procedure for the estimation of climate change impacts on droughts. Nat. Hazards Earth Sys. Sci. 9, 879-894.

Wilby R. L. and T. M. L. Wigley, 1997. Downscaling general circulation model output: A review of methods and limitations. Prog. Phys. Geog. 21, 530-548.

Wilby R. L., T. M. L. Wigley, D. Conway, P. D. Jones, B. C. Hewitson, J. Main and D. S. Wilks, 1998. Statistical downscaling of general circulation model output: A comparison of methods. Water Resour. Res. 34, 2995-3008. 
Wilby R. L., L. E. Hay and G. H. Leavesley, 1999. A comparison of downscaled and raw GCM output: Implications for climate change scenarios in the San Juan River basin, Colorado. J. Hydrol. 225, 67-91.

Wilhelmi O. V. and D. A. Wilhite, 2002. Assessing vulnerability to agricultural drought: A Nebraska case study. Nat. Hazards 25, 37-58.
Wilks D. S., 1995. Statistical methods in the atmospheric sciences: An introduction. Academic Press, New York, 704 pp.

Wu H., M. J. Hayes, D. A. Wilhite and M. D. Svoboda, 2005. The effect of the length of record on the standardized precipitation index calculation. Int. J. Climatol. 25, 505-520. 